\title{
The ecological footprint of building construction
}

\author{
S. Bastianoni, A. Galli, V. Niccolucci \& R. M. Pulselli \\ Department of Chemical and Biosystems Sciences, \\ University of Siena, Italy
}

\begin{abstract}
The aim of this paper is to evaluate the environmental pressure generated by the construction of two types of building, through the application of ecological footprint analysis. The appraisal of the impact of human settlement on the environment is of great concern and environmentally-friendly buildings are actually required. By considering the embodied energy of building materials and the "land area" required to sustain their assembly line, a comparison between the ecological footprint of two typical buildings in the context of Italy is presented. Finally, it is shown that the ecological footprint of building construction can be reduced by using environmentally-inexpensive materials, renewable energy resources and by optimizing bioproductive land use through the construction of multi-storeyed buildings.
\end{abstract}

Keywords: ecological footprint, embodied energy, sustainable urban planning, sustainable building construction.

\section{Introduction}

The current development of urban areas underlines the importance of focusing on cities, buildings and their importance for the human economy. It is also important to consider the consequences of urban area spreading on ecosystem health. Considering people's tendency to live in urban areas, cities are becoming focal points for human life but unfortunately, they are not sustainable. They are cross-roads of most material and energy flows and, at the same time, they contribute to natural capital depletion.

Some concepts from evolutionary thermodynamics could be extended to the city in order to investigate its behaviour with a holistic approach. Each city can 
be considered as an open system and depends on both interactions among its internal elements and exchanges with the external environment. Cities absorb high-quality fluxes of energy and matter from the outside as well as emitting wastes into the external environment (Tiezzi et al [1]). City dependence on external ecosystems shifts environmental impact from the local to the global level (Luck [2]). Houses, buildings, roads and infrastructure require a large amount of resources and can influence material and energy flows in urban areas. Cities can be considered as open evolutionary systems overflowing with structural and infrastructural fauna that feeds on natural capital.

This theoretical framework suggests analyzing cities in terms of entropy flows and entropy production or in terms of resource flows and waste production, leading to more sustainable urban planning.

Internal interactions and exchanges with the external environment are combined properties of evolutionary self-adaptive systems. These two categories also belong to urban dynamics that could be defined as dynamics of cities and dynamics in cities. For example, referring to dynamics of cities, flows of energy and matter that supply an urban system can be studied. Referring to dynamics in cities, patterns of urban interaction and their evolution can be studied.

This assertion leads to a new evolutionary approach for urban studies assuming that some properties and behaviour of an urban system will depend on both the interactions among its parts and between the system and its external environment.

This paper will focus on dynamics of cities, highlighting city dependence on external ecosystems, through the application of the ecological footprint analysis to buildings and their manufacturing process. The appraisal of the impact of human settlement on the environment is of great concern and more environmentally-friendly buildings are currently required. Considering the embodied energy of building materials, the energy spent in the construction process and therefore the "land area" required to sustain the building life cycle, the ecological footprint calculation of two typical Italian buildings is proposed. By optimizing the use of natural capital this analysis demonstrates how to reduce the ecological footprint of buildings, therefore leading to more sustainable building construction and city planning.

\section{Resource consumption in building construction}

The application of sustainable development principles to building construction aims to reduce resource consumption, waste production and environmental impact while warranting the high quality and utility of built-up areas.

In evaluating the dynamics of the construction industry it is important to consider the close interaction that exists between living and non-living structures. This interaction consists of material and energy flows, information and resource flows and it is necessary to understand the evolutive dynamics of the building as a system. In this contest house quality has to be assured while considering natural resources, social needs and national history. Any sustainable building should be able to: 
- make the most of energy resources and natural capital;

- $\quad$ support a part of its energy demand through natural processes;

- use of renewable and local materials;

- reduce its influence on the water cycle;

- reduce $\mathrm{CO}_{2}$ emissions and waste production;

- become part of the surrounding environmental, historical and cultural context.

About $40-50 \%$ of total energy cost in developed countries is closely linked or is a consequence of building construction. Moreover the construction of new buildings, infrastructure and industries, the production and the transport of building materials as well as waste disposal require an increasing amount of bioproductive areas. The significance of this impact requires its measure, here performed by ecological footprint analysis.

These and other global environmental and human-related issues encouraged an increasing number of designers, planners, developers and building users to provide more sustainable urban planning and building construction strategies. The application of sustainability principles and environmental accounting methods to building construction is a consequence of the global environmental problems and it aims to reduce the direct and indirect impact of construction industry with respect to two main issues:

- air pollution due to greenhouse gas emissions;

- depletion of both renewable and unrenewable natural resources (petroleum, natural gas, materials).

One of the main objectives of the application of environmental accounting methods to building construction is to evaluate the impact of common and alternative constructive technologies and materials. These types of analysis are characterized through a life-cycle approach and they are able to direct construction industry and materials choice towards a more sustainable building construction. Building ecology means using and managing natural resources considering not only their economic price and marketing availability, but also their real "environmental value". Their availability in nature depends on time Nature spends for resource renewal and waste disposal and finally, on the Biosphere constraints.

\section{Ecological Footprint Analysis}

The Ecological Footprint Analysis (EFA) was proposed at the beginning of nineties by William Rees and Mathis Wackernagel.

Commonly the Ecological Footprint (EF) of a given population is defined as the ecologically productive land or sea area required to produce, in a sustainable way, all the resources and the ecological services population consume and to absorb, in a sustainable way, wastes and greenhouse gasses population produce, with the prevailing technology and resource management (Rees and 
Wackernagel [3, 4], Wackernagel and Rees [5], Monfreda et al. [6]). Since people use resources from all over the world, and affect faraway places with their pollution, the footprint is the sum of these areas wherever they are on the planet.

$\mathrm{EF}$ is based on the assumption that most of energy and material flows can be converted into the bioproductive area that is required to maintain these flows. It is measured in global hectares (gha) and one global hectare is equivalent to one hectare of bioproductive land with world average productivity.

The account includes six types of bioproductive areas used to support human economy (Wackernagel et al. [7]):

- Cropland for the cultivation of food, animal feed, fibre, oil crops, and rubber;

- Grazing land for producing meat, hides, wool, and milk;

- Forests for harvesting timber, fuelwood, and wood fibre for paper;

- Fisheries for catching fish;

- Built-up areas, ecologically unproductive, used for accommodating infrastructure for housing, transportation, and industrial production;

- Energy land to sequester $\mathrm{CO}_{2}$ emitted from energy and fossil fuels consumption.

EF has a consumer approach to sustainability issues that shows human appropriation and dependence on the natural capital.

Until now EFA was mainly applied to territorial system studies (at global, national or sub-national level) by comparing the EF of local population with the local regenerative capacity (Biocapacity). Biocapacity (BC) is defined as a measure of bioproductive supply, i.e. the biological production of a given area. It is an aggregate of the production of various ecosystems within the area, and it depends on both natural conditions and prevailing farming/forestry practices (Lewan and Simmons [8]).

EF has been recently applied to productive systems in order to evaluate natural capital appropriation, efficiency in natural resource use as well as pressure generating on the environment. Thanks to its consumer approach the application of EF to building sector can provide an interesting evaluation of building dependence on resource production and waste assimilation that occurs at the global scale. EF methodology can be applied to buildings depending on the following assumptions:

- $\quad$ it is possible to keep track of most materials used in a building;

- $\quad$ it is possible to calculate energy embodied in each material through specific embodied energy coefficients;

- $\quad$ use of fuels and energy during material construction and the building erection phase produces an increase of $\mathrm{CO}_{2}$ emissions;

- embodied energy in building materials can be converted into the biologically productive area required to absorb $\mathrm{CO}_{2}$ emissions or to produce materials. 
However, compared to other "products" buildings are more difficult to evaluate for the following reasons. They are large in scale, complex in materials and function and temporally dynamic due to limited service life of building components and changing user requirements. Their production processes are much less standardized than most manufactured goods because of the unique character of each building (Scheuer et al. [9]).

It is simple to calculate the appropriation of bioproductive areas directly required for the physical occupation of land, with respect to dimension, typology and dwellers of a house. Unfortunately, the indirect appropriation of bioproductive land for $\mathrm{CO}_{2}$ absorption and material production, represents one of the most important aspects of EF application to building construction. So EF is able to convert all inputs connected with the life cycle of a building in a single value, expressed in global hectare $(g h a)$. This value represents the direct and indirect appropriation of natural resources and ecological services of a building.

According to Adalberth [10] total energy demand during the life cycle of a building is composed by the energy requirement for building construction (i.e. energy use for producing all the building materials and energy use during the erection phase), energy use during the renovation phase, energy requirement for transportation of materials, energy use during the operation and energy requirement for demolition. This study focuses on the embodied energy in building construction, neglecting energy requirements for transportation, operation phase and demolition.

This study aims to evaluate the consumption of natural resources and the efficiency of building constructional phases, trying to keep track of the most energy expensive factors or, in other words, the factors that more determine the appropriation of bioproductive areas. The appraisal of environmental impact of common and alternative construction methodologies and materials is necessary to reduce energy cost of buildings, emissions of $\mathrm{CO}_{2}$ and $\mathrm{EF}$ of buildings. It has to be considered as a basic knowledge for a more sustainable building construction and urban planning.

\subsection{Embodied energy and other coefficients}

Embodied energy coefficients and the life-span of construction materials, expressed in $\mathrm{MJ} / \mathrm{kg}$ and years respectively, are presented in Table 1. According to Scheuer et al. [9] it was decided to use 5\% of total embodied energy in building materials to account for energy use during the erection phase (i.e. electricity used for power tools and lighting as well as diesel fuel used by heavy equipment at the construction site). Estimates for energy use during the erection phase range in literature from 1.2 to $10 \%$ (Cole et al. [11, 12]).

To convert the amount of primary materials, energy as well as built-up areas into the bioproductive "land area" required for building construction, the conversion factors proposed by Wackernagel et al [13] are used. According to Wackernagel an emission factor of $0.020 \mathrm{~kg}$ of $\mathrm{CO}_{2}$ for each $\mathrm{MJ}$ of average fossil fuel, a global $\mathrm{CO}_{2}$ absorption factor of $0.095 \mathrm{~kg} / \mathrm{m}^{2}$ and an average production factor of $0.125 \mathrm{~kg}$ of timber for square meter of forest is used. 
Assuming that energy expenses due to the use of natural products, such as timber and cork, are compensated by the absorption of $\mathrm{CO}_{2}$ through trees during their growth, a hypothesis of zero emission factor has been considered.

Table 1: Embodied energy coefficients and life-span of building materials.

\begin{tabular}{|l|c|c|}
\hline Type of material & $\begin{array}{l}\text { Embodied } \\
\text { energy } \\
\text { (MJ/kg) }\end{array}$ & $\begin{array}{l}\text { Life span } \\
\text { of materials } \\
\text { (years) }\end{array}$ \\
\hline Gravel & $0.2_{b}$ & $75_{b}$ \\
\hline Concrete & $1.2_{a}$ & $75_{b}$ \\
\hline Structural steel & $32.0_{a}$ & $75_{b}$ \\
\hline Asphalt & $50.2_{b}$ & $75_{b}$ \\
\hline Hollow concrete bricks & $0.7_{c}$ & $75_{b}$ \\
\hline Hollow clay bricks & $2.5_{a, b}$ & $75_{b}$ \\
\hline Ceramic floor and wall tile & $2.5_{a}$ & $75_{b}$ \\
\hline Ceramic tile - roofs claddings & $2.5_{a}$ & $20_{b}$ \\
\hline Stoneware & $18.93_{d}$ & $75_{b}$ \\
\hline Glass & $15.9_{a}$ & $40-50_{d}$ \\
\hline Raw aluminium & $191.0_{a}$ & $50_{d}$ \\
\hline Timber - veneer dried in autoclave & - & $50_{b}$ \\
\hline Cement rendering & $7.8_{a}$ & $5_{b}$ \\
\hline Cork sheets & - & $40_{d}$ \\
\hline
\end{tabular}

References in Table 1: a refers to data from González and Navarro [14]; $b$ refers to data from Scheuer et al. [9]; $c$ refers to our estimates on data coming from Venkatarama Reddy and Jagadish [15] and $d$ refers to data from CRAS [16].

In order to evaluate the annual appropriation of natural resources and ecological services due to building construction, the life-span of each construction materials is considered. Adding up the annual contribution of every material the value of building ecological footprint is obtained.

\section{Results and discussion}

Here we discuss the results derived from the EF calculation of two typical Italian buildings with approximately $150 \mathrm{~m}^{2}$ of housing surface for each floor:

a. a two-storeyed detached house with a reinforced concrete structure, hollow clay brick walling, cork sheets insulation, aluminium window frame, timber door, ceramic wall and floor finishing and cement rendering claddings.

b. a four-storey condominium built-up with the same materials and constructional process. 


\subsection{Building footprint}

This section provides the results of EFA calculation underlining the dynamics involved in building construction and the appropriation of natural resources and ecological services through the selected buildings (Table 2).

Table 2: Comparison between the building energy and ecological values.

\begin{tabular}{|l|c|c|l|}
\hline & $\begin{array}{l}\text { Detached } \\
\text { house }\end{array}$ & $\begin{array}{l}\text { Four-storey } \\
\text { condominium }\end{array}$ & Units \\
\hline Built-up area & 160 & 160 & $\mathrm{~m}^{2}$ \\
\hline Total embodied energy & 1,833 & 2,660 & $\mathrm{GJ}$ \\
\hline Housing surface & 300 & 600 & $\mathrm{~m}^{2}$ \\
\hline Embodied energy & 6.11 & 4.44 & $\mathrm{GJ} / \mathrm{m}^{2}$ \\
\hline Ecological Footprint & 6,290 & 9,465 & $\mathrm{gm}^{2}$ \\
\hline EF/Built-up area & 39 & 59 & $\mathrm{gm}^{2} / \mathrm{m}^{2}$ \\
\hline Dwellers & 5.2 & 10.4 & inhabit. \\
\hline EF per capita & 0.122 & 0.091 & gha per capita \\
\hline
\end{tabular}

Total embodied energy over the building life cycle ranges from 4.44 to 6.11 $\mathrm{GJ} / \mathrm{m}^{2}$ for the four-storey condominium and the detached house respectively. These values fall within the range of $2-12 \mathrm{GJ} / \mathrm{m}^{2}$ cited in literature.

From an energy point of view, Table 2 shows that the embodied energy of the detached house is $30 \%$ smaller than that of the four-storey condominium. Moreover, from a landscape point of view the detached house is better integrated in the environmental, historical and cultural context of Italy. At the same time, thanks to its vertical growth the four-storey condominium is characterized by a wider housing surface that determines a minor embodied energy per square meter of housing surface.

EF values highlight that the construction of the selected buildings determines an annual bioproductive areas requirement of 6,290 and $9,465 \mathrm{gm}^{2}$ respectively. The direct requirement of real land for building construction, i.e. the built-up area, hides a consistent indirect requirement of bioproductive areas, needed to provide all raw materials and to absorb all $\mathrm{CO}_{2}$ emitted in the constructional phase. For the detached house and the four-storey condominium this "ghost land" is 39 and 59 times as big as the built-up area respectively.

It is important to underline that the four-storey condominium is able to annually accommodate a greater number of dwellers by means of the wider housing surface. For the detached-house and the condominium, two and four apartments are in that order estimated. Considering that each apartment of the selected buildings is dwelled by a family as well as an average Italian family is made up of 2.6 people (ISTAT [17]), the detached house and the condominium annually accommodate 5.2 and 10.4 people correspondingly. This leads to an annual per capita ecological footprint value of 0.12 and 0.09 global hectares respectively. 
These values are slightly greater than those proposed by Wackernagel pertaining to the typical Canadian wood-made houses. Results here obtained are more strictly related to reinforced concrete buildings that are typical of the European building construction. All these characteristics make the results obtained applicable to the analysis of the ecological footprint of Italian territorial systems.

Moreover it is interesting to compare these results with the worldwide average biocapacity per capita (1.90 gha), defined as the annual amount of bioproductive land that people should have at their disposal by means of the equal distribution of natural resources. The percentage of EF that each average Italian citizen requires for building construction ranges from $4.8 \%$ (four-storey condominium) to $6.4 \%$ (detached house) of the overall biocapacity. Finally it is possible to compare EF values with the Italian average biocapacity, 1.18 gha per capita. EF component due to building changes to $7.7 \%$ and $10.4 \%$ respectively.

Thus, through the construction of multi-storeyed buildings it is possible to reduce both the direct and indirect demand of built-up and bioproductive areas correspondingly. For allocating 10 dwellers the selected four-storey condominium requires about $160 \mathrm{~m}^{2}$ of built-up area; at the same time, for allocating the same number of dwellers, two detached house are requested. This leads to an increase of built-up areas that replace natural bioproductive areas contributing to the depletion of the global natural capital. This is even more important considering the continuous increase of the world population and the global tendency to live in urban areas.

Keeping in mind Earth biophysical constraints, biogeochemical cycle dynamics and natural rate of resource production in regard to human rate of consumption, is necessary to direct future building planning towards more environmentally-inexpensive buildings.

\subsection{Unpacking the ecological footprint of building construction}

To deeper understand the EF values of the selected buildings, data are presented for both building structural elements (see Table 3) and building materials (see Table 4).

Focusing on "land area" categories, Table 3 shows that the construction of a typical Italian building requires a large amount of Energy land (90\%) while requiring Forests and Built-up areas in a small scale (about $5 \%$ each of them). Focusing on structural elements, high demand of natural capital for Foundations is evident. This category includes consolidation and foundation works. It is interesting to compare the bioproductive land requirement for Foundations by the detached house and the four-storey condominium. It ranges from $33 \%$ to $23 \%$ of the total footprint value respectively. These values underline the environmental cost of Foundations in building construction. Most of natural resources and ecological services are required for this structural element which more contributing to the global natural capital depletion. Thus, in the construction of a building it is very important to optimize environmental costs by means of multi-storeyed buildings. 
Table 3: Ecological footprint by structural elements and types of land areas of the selected buildings.

\begin{tabular}{|c|c|c|c|c|c|}
\hline Detached House & $\begin{array}{c}\text { Energy land } \\
\mathrm{gm}^{2}\end{array}$ & $\begin{array}{l}\text { Forest } \\
\mathrm{gm}^{2}\end{array}$ & $\begin{array}{c}\text { Built-up area } \\
\mathrm{gm}^{2}\end{array}$ & $\begin{array}{c}\text { TOTAL } \\
\mathrm{gm}^{2}\end{array}$ & $\%$ \\
\hline Foundations & 2,058 & - & - & 2,058 & $33 \%$ \\
\hline Structure and slabs - ground floor & 1,139 & - & - & 1,139 & $18 \%$ \\
\hline Structure and slabs - 1st floor & 1,059 & - & - & 1,059 & $17 \%$ \\
\hline Roof structure and claddings & 842 & - & - & 842 & $13 \%$ \\
\hline Floor and wall tiling and plastering & 190 & - & - & 190 & $3 \%$ \\
\hline Window and door frame & 325 & 194 & - & 519 & $8 \%$ \\
\hline Sanitary fittings & 20 & - & - & 20 & $0.3 \%$ \\
\hline Insulation & - & 116 & - & 116 & $2 \%$ \\
\hline Built-up area & - & - & 347 & 347 & $6 \%$ \\
\hline Total ecological Footprint & 5,633 & 310 & 347 & 6,290 & $100 \%$ \\
\hline Four-storey condominium & $\begin{array}{c}\text { Energy land } \\
\mathrm{gm}^{2}\end{array}$ & $\begin{array}{l}\text { Forest } \\
\mathrm{gm}^{2}\end{array}$ & $\begin{array}{c}\text { Built-up area } \\
\mathrm{gm}^{2}\end{array}$ & $\begin{array}{l}\text { TOTAL } \\
\mathrm{gm}^{2}\end{array}$ & $\%$ \\
\hline Foundations & 2,165 & - & - & 2,165 & $23 \%$ \\
\hline Structure and slabs - ground floor & 1,139 & - & - & 1,139 & $12 \%$ \\
\hline Structure and slabs - 1st floor & 1,059 & - & - & 1,059 & $11 \%$ \\
\hline Structure and slabs - 2nd floor & 1,059 & & & 1,059 & $11 \%$ \\
\hline Structure and slabs - 3rd floor & 1,059 & & & 1,059 & $11 \%$ \\
\hline Roof structure and claddings & 842 & - & - & 842 & $9 \%$ \\
\hline Floor and wall tiling and plastering & 452 & - & - & 452 & $5 \%$ \\
\hline Window and door frame & 682 & 388 & - & 1,070 & $11 \%$ \\
\hline Sanitary fittings & 41 & - & - & 41 & $0.4 \%$ \\
\hline Insulation & - & 231 & - & 231 & $2 \%$ \\
\hline Built-up area & - & - & 347 & 347 & $4 \%$ \\
\hline Total ecological Footprint & 8,499 & 619 & 347 & 9,465 & $100 \%$ \\
\hline
\end{tabular}

Table 4 shows natural capital appropriation through building materials. For the detached house, most of EF value is due to the use of Concrete (for Foundations and Structure and slabs) and Asphalt (for foundation waterproofing). Asphalt is an environmentally-expensive material with a high embodied energy per mass unit. It requires a large amount of Energy land for its production even if it is used in a very small quantity. EF component due to Asphalt ranges from $21 \%$ for the detached house to $14 \%$ for the four-storey condominium. Once more EF values demonstrate the need of a more sustainable building construction by choosing multi-storeyed buildings able to reduce the Ecological Footprint of building construction system. Moreover, the choice of multi-storeyed buildings causes an important reduction in soil waterproofing, and decreases the risk of the water cycle alteration.

In addiction to this, it is important to underline the contribution of aluminium to total bioproductive land requirement. Raw aluminium has an extremely high embodied energy per $\mathrm{kg}$ and it is used for door and windows frame. The EF value of a raw aluminium window frame (size: $1.3 \mathrm{~m} \mathrm{x} 1.5 \mathrm{~m} \mathrm{x} 0.04 \mathrm{~m}$ ) is about $30 \mathrm{gm}^{2}$ of Energy land while a timber window frame with the same size requires about $2 \mathrm{gm}^{2}$ of Forests. These results demonstrate the importance of natural products in building construction. The choice of energetically-inexpensive and environmentally-friendly materials like timber can reduce the ecological footprint of Window and door frame up to $90 \%$. 
Even if this category contributes only in a minor part to the overall building footprint, it is possible to reduce total natural capital appropriation of buildings up to $3.5 \%$ by choosing these materials. Note that these types of precautions could be extended to all building structural elements.

Table 4: Ecological footprint by building materials and types of land areas of the selected buildings.

\begin{tabular}{|c|c|c|c|c|c|}
\hline Detached House & $\begin{array}{l}\text { Energy land } \\
\mathrm{gm}^{2}\end{array}$ & $\begin{array}{c}\text { Forest } \\
\mathrm{gm}^{2}\end{array}$ & $\begin{array}{c}\text { Built-up area } \\
\mathrm{gm}^{2}\end{array}$ & $\begin{array}{c}\text { TOTAL } \\
\mathrm{gm}^{2}\end{array}$ & $\%$ \\
\hline Gravel & 96 & & & 96 & $2 \%$ \\
\hline Concrete & 1,656 & & & 1,656 & $26 \%$ \\
\hline Raw steel - reinforcement & 947 & & & 947 & $15 \%$ \\
\hline Asphalt & 1,349 & & & 1,349 & $21 \%$ \\
\hline Hollow concrete bricks & 742 & & & 742 & $12 \%$ \\
\hline Hollow clay bricks & 90 & & & 90 & $1 \%$ \\
\hline Ceramic & 183 & & & 183 & $3 \%$ \\
\hline Ceramic tile - roofs claddings & 223 & & & 223 & $4 \%$ \\
\hline Stoneware (grès) & 16 & & & 16 & $0.3 \%$ \\
\hline Glass & 38 & & & 38 & $1 \%$ \\
\hline Raw aluminium & 287 & & & 287 & $5 \%$ \\
\hline Timber - veneer dried in autoclave & & 194 & & 194 & $3 \%$ \\
\hline Plaster & 7 & & & 7 & $0.1 \%$ \\
\hline Cork sheets & & 116 & & 116 & $2 \%$ \\
\hline Land use & & & 347 & 347 & $5.5 \%$ \\
\hline Total ecological Footprint & 5,633 & 310 & 347 & 6,290 & $100 \%$ \\
\hline Four-storey condominium & $\begin{array}{c}\text { Energy land } \\
\mathrm{gm}^{2}\end{array}$ & $\begin{array}{c}\text { Forest } \\
\mathrm{gm}^{2}\end{array}$ & $\begin{array}{c}\text { Built-up area } \\
\mathrm{gm}^{2}\end{array}$ & $\begin{array}{c}\text { TOTAL } \\
\mathrm{gm}^{2}\end{array}$ & $\%$ \\
\hline Gravel & 111 & & & 111 & $1 \%$ \\
\hline Concrete & 2,619 & & & 2,619 & $28 \%$ \\
\hline Raw steel - reinforcement & 1,501 & & & 1,501 & $16 \%$ \\
\hline Asphalt & 1,349 & & & 1,349 & $14 \%$ \\
\hline Hollow concrete bricks & 1,376 & & & 1,376 & $15 \%$ \\
\hline Hollow clay bricks & 154 & & & 154 & $2 \%$ \\
\hline Ceramic & 438 & & & 438 & $5 \%$ \\
\hline Ceramic tile - roofs claddings & 223 & & & 223 & $2 \%$ \\
\hline Stoneware (grès) & 32 & & & 32 & $0.3 \%$ \\
\hline Glass & 68 & & & 68 & $1 \%$ \\
\hline Raw aluminium & 614 & & & 614 & $6 \%$ \\
\hline Timber - veneer dried in autoclave & & 388 & & 388 & $4 \%$ \\
\hline Plaster & 14 & & & 14 & $0.1 \%$ \\
\hline Cork sheets & & 231 & & 231 & $2 \%$ \\
\hline Land use & & & 347 & 347 & $3.7 \%$ \\
\hline Total ecological Footprint & 8,499 & 619 & 347 & 9,465 & $100 \%$ \\
\hline
\end{tabular}

Finally, it should be taken into account the fact that timber, cork and other wood products are able to compensate the $\mathrm{CO}_{2}$ emissions that rise from their use through the negentropic work of the photosynthesis.

\section{Conclusions}

By integrating a common embodied energy analysis with EFA it is possible to assess not only energy expenses but also natural capital appropriation of buildings, adding up all inputs into a single value. Based on these parameters the 
assessment of building impact, enables to find a common language between architectural and ecological disciplines and to generate useful analysis for establishing sustainability parameters for building construction and urban planning.

Results presented in this paper demonstrate the minor environmental pressure generated by multi-storeyed buildings, in respect to detached houses, in the Italian contest. Minor natural capital requirement in multi-storeyed buildings is due to:

- major number of dwellers for each building;

- sharing of Built-up area;

- less requirement of bioproductive land and more natural capital saving;

- Optimization of the environmental burdens due to environmental expensive structural elements (i.e. Foundations).

In addiction to this, it is important to consider the land area saving that results through the use of local building materials and renewable energy sources in the building constructional phase.

EFA by building materials shows the importance of natural materials like wood and cork in $\mathrm{CO}_{2}$ reduction and, in general, in the reduction of "ghost land" requirement.

Finally, it is undeniable the importance of saving the natural capital, the actual limiting factor. So, thanks to the application of EFA to building construction it is possible to assess building appropriation of the natural capital and to suggest useful options reducing this appropriation.

For this reasons, this article suggests a comparison between the EF values of the two typical Italian buildings and both the global and the Italian average per capita BC. The appropriation of natural resources and ecological services for building construction ranges from $4.8 \%$ (four-storey condominium) to $6.4 \%$ (detached house) of the overall $\mathrm{BC}$, while it changes to $7.7 \%$ and $10.4 \%$ respectively if compared with the local average BC.

House sharing, the reduction of Built-up area as well as choosing natural materials and multi-storeyed buildings is necessary to reduce and optimize the appropriation of bioproductive land in building construction. All these precautions foster the conservation of the natural capital and the reduction of $\mathrm{CO}_{2}$ emissions for the benefit of current and future generations.

\section{References}

[1] Tiezzi, E., Steps Towards an Evolutionary Physics, WIT Press, in press.

[2] Luck, M.A., Darrel Jenerette, G., Wu, J., Grimm, N.B., The Urban Funnel Model and the Spatially Heterogeneous Ecological Footprint, Ecosystems 4, 782-796, 2001.

[3] Rees, W.E., Wackernagel, M., Urban Ecological Footprints: why cities cannot be sustainable - and why they are a key to sustainability, Environ impact assess rev 16, 223-248, 1996. 
[4] Rees, W.E., Ecological footprints and appropriated carrying capacity: what urban economics leaves out, Environment and Urbanization 4(2), 121-130, 1992.

[5] Wackernagel, M., Rees, W.E., Our ecological footprint: reducing human impact on the earth, New Society Publishers, Gabriola Island, British Columbia, Canada, 1996.

[6] Monfreda, C., Wackernagel, M., Deumling, D., Establishing national natural capital accounts based on detailed Ecological Footprint and biological capacity assessments, Land Use Policy 21, 231-246, 2004.

[7] Wackernagel, M., Monfreda, C., Deumling, D., Ecological Footprint of nations, November 2002 update: How much nature do they use? How much nature do they have? Redefining progress, sustainability issue brief, November 2002.

[8] Lewan, L., Simmons C., The use of Ecological Footprint and Biocapacity Analyses as Sustainability Indicators for Sub-national Geographical Areas: a Recommended way Forward, European Common Indicators Project EUROCITIES/ Ambiente Italia, 2001.

[9] Scheuer, C., Keoleian G.A., Reppe, P., Life cycle energy and environmental performance of a new university building: modelling challenges and design implications, Energy and Buildings 35, 1049-1064, 2003.

[10] Adalberth, K., Energy use during the Life Cycle of Buildings: a Method, Building and Environment 32, 317-320, 1997.

[11] Cole, R.J., Rousseau, D., Environmental auditing for building construction: energy and air pollution indices for building materials, Building and Environment 27, 23-30, 1992.

[12] Cole, R.J., Kernan, P.C., Life-cycle energy use in office buildings, Building and Environment 31, 307-317, 1996.

[13] Wackernagel, M., Monfreda, C., Deumling, D., Dholakia, R., Household Ecological Footprint Calculator, v 3.2, Redefining Progress, http://www.rprogress.org, 2003.

[14] González, M.J., Navarro J.G., Assessment of the decrease of $\mathrm{CO}_{2}$ emissions in the construction field through the selection of materials: Practical case study of three houses of low environmental impact, Building and Environment, in press.

[15] Venkatarama Reddy, B.V., Jagadish K.S., Embodied energy of common and alternative building materials and technologies, Energy and Buildings, 35, 129-137, 2003.

[16] CRAS, Ecological Footprint - Un approfondimento sull'impronta ecologica dell'edilizia residenziale in Italia, International Association for Environmental Design (IAED), 2004.

[17] ISTAT, Annuario Statistico Italiano 2004, Rubbettino - Industrie Grafiche ed Editoriali, Soveria Mannelli (CZ), 2004. 